\title{
Observation, research and natural sciences as part of the medical education.
} The historical context.

\author{
Orsolya Horber ${ }^{1 *}$, Karoly Zilahi $^{2}$ \\ Praxis Dr.Horber-Dr.Zilahi, Romania
}

\begin{abstract}
The relationship between natural sciences and medicine has been a great deal closer throughout the history of medicine in Transylvania than it is nowadays. The physicians of the second half of the eighteenth century were accustomed to analyse the composition of mineral waters, to hike along the Carpathian Mountains, to collect botanical and mineral rarities and send them to the nearest gymnasium in order to be studied. The interdisciplinarity, the medical and natural sciences societies, the museums and the collections founded during the Enlightenment years played a great part in the history of medical education and helped shape professional medicine.
\end{abstract}

Keywords:medical education, natural sciences, observation,interdisciplinarity, The Transylvanian Museum Society

When Emile Zola writes in his essay "Le Roman Experimental" ("The Experimental Novel") about the similarities between the work of the writer and that of the researcher, he is, in fact, pointing to a very important feature of the medical sciences: they are empirical and based on observation. According to Claude Bernard, a physician would observe, synthesize and analyze the information and, later on, by means of various experiments, prove these findings to be correct. Zola was a great admirer of Claude Bernard's "Introduction to the experimental medicine" and describes the work of the author as being a continuation of scientific, medical and physiological observation. In turn, the physician will continue the work of physicists and chemists in Zola's opinion. [1]

The observation of nature and of the human being is indeed a trait that both literature and sciences share. The physician resorts to his own experiments in his activity and, also, to information gathered and structured for centuries by others before him. Nowadays, however, as a result of very rapid means of communication, the objective reviewing of information is getting harder to achieve. Nonetheless, the natural sciences and direct observation of nature and the human being have played a very im- portant part in medical education and the progress of modern medicine.

We will look at the part natural sciences have played in the medical education and place it within a historical context (centuries XVIII-XIX), underlining aspects particular to Transylvania:

1. The physician as a traveller- the physician as an observer. The physician and natural sciences

2. The portrait of the physician in Age of Enlightenment

3. Professional and medical societies. Correspondencethe exchange of letters

4. Collections and museums. The Transylvanian Museum Society

1. The physician as a traveller- the physician as an observer. The physician and natural sciences

Medieval Transylvania had no specialized medical institutions or medical universities; as a result, physicians from other countries would come here to practice medicine, while young Transylvanian people would travel to different European universities in order to study medicine. Throughout the fifteenth to the sixteenth centuries, Romanians have preferred the medical institutions of Padua and Wien; later on, they mainly chose German universities (Wittenberg, Tubingen, Strasbourg); during the seventeenth to the eighteenth centuries, the Romanians would study medicine in Utrecht and Leiden, but also in French or English institutions.[2].

"Peregrinatio academica" was a big part of the education of a physician in Transylvania; most of the times, the young doctors to be would spend a couple of semesters with a prestigious university then travel to a different one. The theories and information gathered in the process and brought back home would gradually replace the medieval scholastics. In Padua for instance, there was a very important neo-Aristotelian movement going on; Petrarca would ridicule the scholars and encourage the physicians to resort to the observation of nature and to the real practice of medicine: "Quid est opus verbis? Cura, semper dixi, medice!" 
The physician-philosopher was gradually being replaced by a much more educated doctor, one that was in better contact with the natural sciences.[3]

Throughout the eighteenth century, the physicians in Transylvania would collect minerals and take up botany and zoology. Hiking across the Carpathian Mountains and meteorological observation were favourite pursuits of the physicians of those times. In 1799 for instance, they were urged to send the rare anatomical and pathological material they had stumbled upon during their surgical interventions, autopsies or births to the museums, in order to studied and documented. Starting with 1763, physicians from different regions had to study the mineral waters in the vicinity of their practice and describe their composition.[2]

Mineralogy, botany, zoology or meteorology were sciences of interest to the physicians representatives of the enlightenment in Transylvania. Throughout the history of medicine, the connection to the natural sciences has been a great deal closer than it is today; naturally, it contributed to a more solid general education of the physician, facilitating in some cases the recovery of the patients.

\section{The portrait of the physician in the Age of Enlighten-} ment

During the great London plague (1665-1666), even Sydenham, the practitioner, admits to having left the city.[2]. Social responsibility was a concept unknown to physicians of those times. Not even the State had any particular concern with public health at that time.

The publication of Human Rights changed the relationship between the physician and his patients. The medieval "hospitale xenodochium" were replaced by the proper hospitals. The poor were treated for less money. Children homes are being built. Physicians come up with ways to better position cemeteries and to eliminate centres of contagion.

Moses Mendelssohn promoted religious tolerance. Back in those times, the physician would become more tolerant, more sensible, a bit of a philosopher, a philanthropist even, or a politician (portraits characteristic to the enlightenment, as outlined by Dorina Outram).[4].

Sydenham was documenting the traits of the plague as a practitioner but did not feel any responsibility to actually treat it. During the Enlightenment, the physician would observe nature and the human being, connecting him to fellow human beings (patients but, also, other physicians) and apply "a set of values common to all of them: freedom, justice, objectivity" (Habermas); these values were very important during the Enlightenment years.[4].

Once the condition of the physician had evolved, it was only fair for the status of the patient to change as well. The Enlightenment meant the formation of the middle class and the acknowledgment of individual responsibility. The medical education of the time focused on the observation of the human being as well: the consultation, the examination by percussion or auscultation, the enquiry into the antecedents of the patient. The natural sciences and anatomy (even "the art of anatomy" or "the anatomical theatres") become some of the main topics within medical faculties.

3. Professional and medical societies.Correspondence- the exchange of letters

Common values such as freedom or objectivity, the sharing of the same profession or the fact that people studied at the same university, gave place to the exchange of letters between physicians. This meant a true exchange of experience and science. Some of those letters were, in fact, "scientific essays"; the resemblance to the publications of the twenty-first centuries is truly remarkable.

Common goals also meant the setting up of professional societies and associations. In Transylvania, the physicians would often pair up with natural sciences researchers for this. Scientific societies promoted observation and research but, at the same time, had the purpose of spreading scientific knowledge among the population, thus contributing to the creation of the middle class, the main consumer of culture (Habermas). To this end, books are being published, collections are being put together and, at times, theatre plays are being acted out.

4. Collections and museums. The Transylvanian Museum Society

The classical physicians had important collections of rare books, codex or coins. The scholar Apaczai Csere Janos for instance, promoted the foundation of a botanical garden in Transylvania; this will actually happen at the beginning of the twentieth century, in Cluj.

During the second half of the eighteenth century, physicians in Transylvania were urged to produce collections of mineral or botanical rarities and send them over to the nearest gymnasium $(1781,1786)$.[3]

In 1859, The Transylvanian Museum Society(TMS) is founded; the contract mentioned the establishment of a museum, the processing of scientific material and the spreading of the results.

The scientific methods employed by the Transylvanian Museum Society were the scientific departments and the collections. This meant the foundation of different departments: philology and history, medical and pharmaceutical, mathematics, law or agriculture.

The members of the society would hold annual conferences, starting with 1906; this allowed for permanent gettogethers and the publication of specialised books, as a result of the works presented during the conferences.

In the meantime, the society helped put together a very important collection: when the museum was nationalized, the State took over a library of 120000 books, 35000 archaeological items, a coin collection and a very impressive collection of minerals, zoological and geological material.[5] 


\section{Conclusions}

1. The relationship between natural sciences and medicine has been much closer throughout the history of medicine in Transylvania than it is today: physicians would observe and analyse nature, hike across the Carpathian Mountains, put together botanical, zoological or mineral collections.

2. During the seventeenth to the nineteenth centuries Transylvania had quite a number of scientists well educated that would dedicate themselves to different brunches of science (philosophy, mathematics, literature, natural sciences).

There was also the specialised researcher that would mainly take up on one science and professionally engage in it (for instance the math specialist Bolyai Janos). Ignaz Edler von Born, born in 1742 in Cavnic (Transylvania) was a dedicated mineralogist. He had an important library and mineral collection and contributed to the foundation of the first international scientific society (Societat der Bergbaukunde -SDB).

3. The interdiscplinarity, the medical and natural sciences societies, the collections and the museums, all played a very important part in the development of the medical education and the foundation of professional medicine.

4. The twenty-first century physician uses a computer and learns about the new discoveries over the Internet but is oblivious to the knowledge on soil or water composition. Medicine today is getting harder to practice due to the great amount of information available. However, familiarity with some of the aspects of natural sciences (botany, geology, the chemistry of the soil and waters) would be a great addition to medical education and would contribute to the increase in the quality of the curing process. The curing process needs to always be simple ("Simplex veri sigillum" - "the main feature of the truth is its simplicity"), in the words of Boerhaave (a scientist, a practitioner and a professor, considered to be the founder of the clinical medical education).

\section{References}

[1].Horvath,A:,Utoszo:Emile Zola Tisztes urihaz, Kriterion Konyvkiado, Bukarest, 1987

[2].Szumowski U: Az orvostudomany tortenete ,1939

[3]. Horber O., Zilahi K.: The importance

of education in the humanities in medical training. Professional decisisions between

succes and failure, Romanian Journal of Bioethics, Vol.7, Nr.2, pg 108-112

[4].Outram,D:Panorama Iluminismului,Editura ALL,2008

[5].www.eme.ro 